\title{
The impact of water conservation using sedrainpond and infiltration wells on surface water quantities: a case study of the Pakopen micro watershed, Semarang District, Central Java, Indonesia
}

\author{
Ignatius Sriyana ${ }^{1, *}$ \\ ${ }^{1}$ Department of Civil Engineering, Faculty of Engineering, Diponegoro University, Semarang, \\ Indonesia
}

\begin{abstract}
Due to the increasing amounts of surface runoff and land degradation in watersheds, mitigation efforts need to be taken by adopting water conservation technologies to reduce flooding and surface runoff. The purpose of this research is to study the impact of sedrainpond (SDP) and infiltration well technology procurement on surface water in order to mitigate flood disasters downstream. The method approach is carried out by measuring the field discharge, collecting rainfall data and analysing the data using ArcView GIS and Microsoft Excel. The measured discharge in the study was $1170.9 \mathrm{~L} / \mathrm{s}$. The study applies 1819 units of SDP technologies with a diameter of $1 \mathrm{~m}$, a depth of $2.5 \mathrm{~m}$ and a total storage volume of $3573.11 \mathrm{~m}^{3}$, and 340 units of infiltration wells with a diameter of $1 \mathrm{~m}$, a depth of 2 $\mathrm{m}$ and a total storage volume of $533.65 \mathrm{~m}^{3}$. For scenario 1 , where the water contained in the well is drained in one day, the flood discharge can be reduced to $986 \mathrm{~L} / \mathrm{s}$, along with a flow rate decrease of $184.9 \mathrm{~L} / \mathrm{s}(15.79 \%)$. While for scenario 2 , where the water contained in the well is drained in two days, the flood discharge can be reduced to $1001.6 \mathrm{~L} / \mathrm{s}$ with a flow rate decrease of $184.9 \mathrm{~L} / \mathrm{s}(14.46 \%)$.
\end{abstract}

\section{Introduction}

Water is one of the most important sources of life for all living beings [1]. Current water levels are uncertain because of excess water during the rainy season and a lack of water during the dry season. This is due to increased land degradation in watersheds, as a result of land changes by communities due to increasing land development. Therefore, it is a challenge [2] to conserve soil and water as a disaster mitigation effort. Disaster mitigation is carried out in anticipation of floods and droughts, so the application of technology has an important role [3] to reduce the risk of a disaster. The technology of sedrainpond (SDP) [4], as an appropriate technology built on paddy fields belonging to farmers, does not only serve as soil conservation but also functions as water conservation, including infiltration wells built in yardlands [5]. SDP technology and infiltration wells can trim the flood discharge or

* Corresponding author: $\underline{\text { sriyana@live.undip.ac.id }}$ 
reduce surface water. Both these appropriate technologies are applied to different locations (in paddy fields and in settlements). Both of these technologies are viewed from a significant and measurable storage capacity but have not been combined as rainwater catchments, in order to reduce flood discharge or surface flow. The purpose of this research is to study the impact of SDP technology development and infiltration wells on surface water in order to mitigate flood disasters downstream.

\section{Material and methods}

\subsection{Research area}

The study site is located at the Pakopen micro watershed, Semarang District, Central Java Province, Indonesia. Geographically, the Pakopen micro watershed is located at the coordinates of $7^{\circ} 11^{\prime} 17.03$ "S - $110^{\circ} 23^{\prime} 16.32^{\prime \prime}$ E. The area of Pakopen micro watershed is 260.85 hectares, comprising Pakopen village with an area of 59.07 hectares, Munding village with an area of 181.39 hectares, Sidomukti village with an area of 4.85 hectares and Duren village with an area of 15.53 hectares.

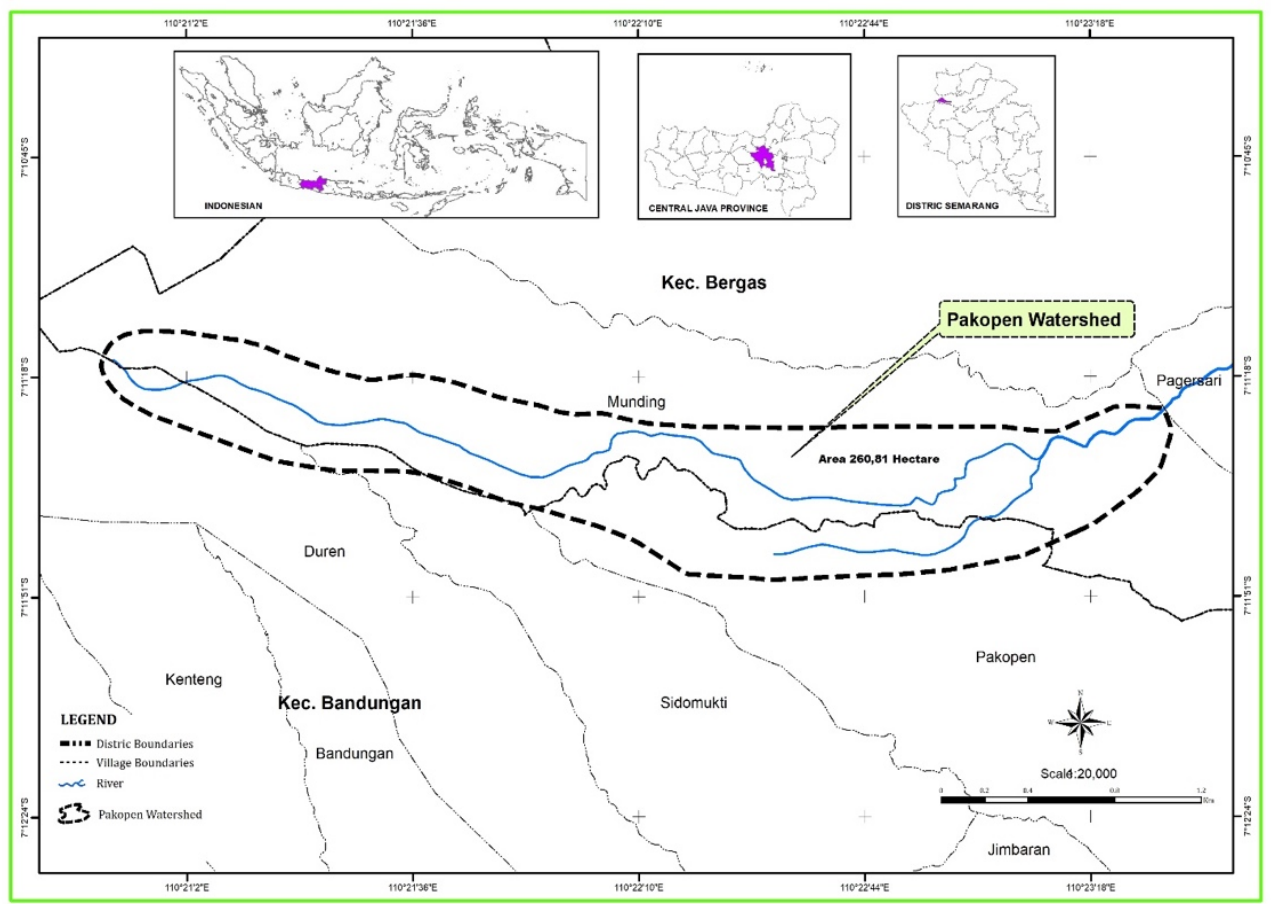

Fig. 1. Location map of discharge measurement.

\subsection{Method}

The river flow is measured using a current meter. The location map is created using the ArcView GIS program. All data are analysed using Microsoft Excel. The stages in the data analysis process are calculating the flow volume of the watershed based on monthly rainfall data and calculating the flow volume after conservation using SDP and infiltration wells. 


\subsection{Hydrology observations and measurements}

Observations were made for the water level, water discharge and rainfall to obtain the data used as the basis for determining the runoff coefficient. The observation of the water level is based on rain conditions in the field. There are five water surface data obtained, namely, on April 17, 2017, April 20, 2017, April 21, 2017, April 23, 2017, and April 26, 2017.

The peak of the water level on April 17, 2017 is $12 \mathrm{~cm}$ occurring at 18.00, on April 20, 2017 is $16.2 \mathrm{~cm}$ occurring at 14:40, on 21 April 2017 is $8.2 \mathrm{~cm}$ occurring at 15:20, on 23 April 2017 is $11.8 \mathrm{~cm}$ occurring at 18.00 and at 26 April 2017 is $18.6 \mathrm{~cm}$ occurring at 14:40. The results can be seen in Figures 2 to 6 .

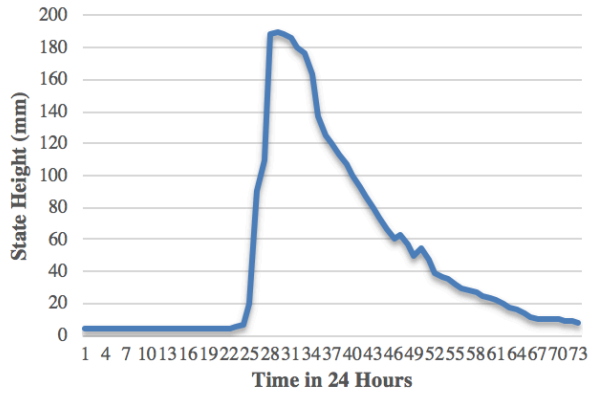

Fig. 2. Stage hydrograph for 17 April, 2017.

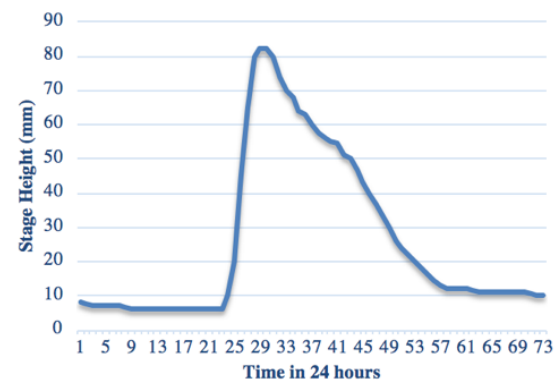

Fig. 4. Stage hydrograph for 21 April, 2017.

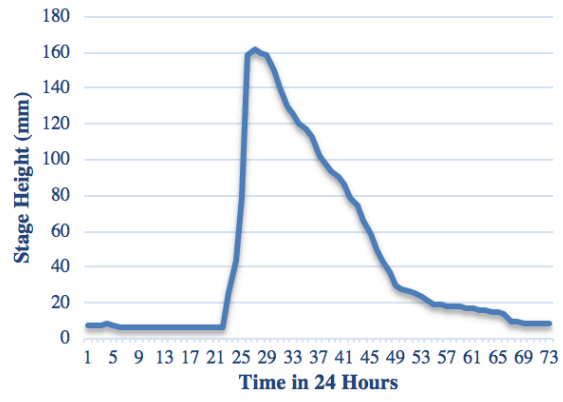

Fig.3. Stage hydrograph for 20 April, 2017.

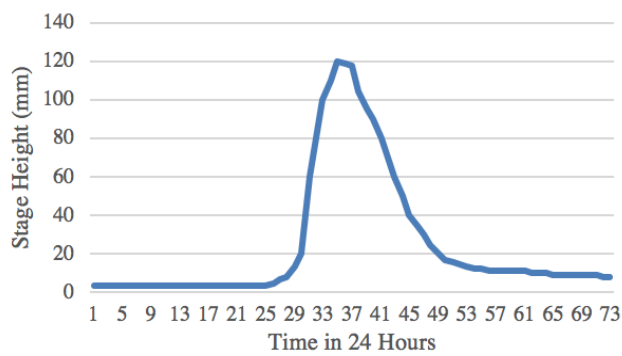

Fig. 5. Stage hydrograph for 23 April, 2017.

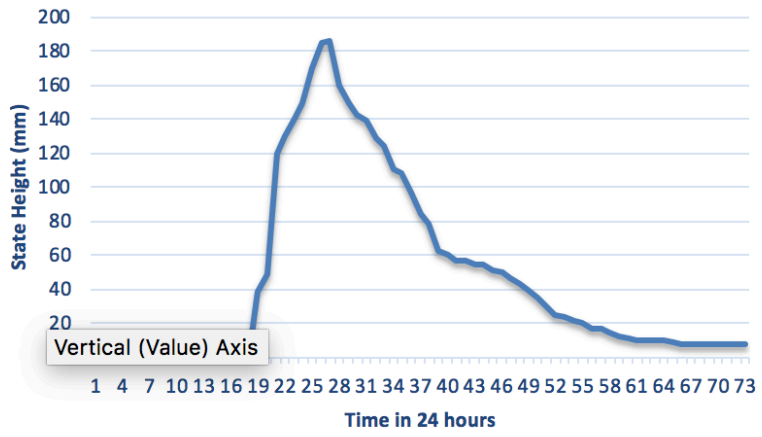

Fig.6. Stage hydrograph for 26 April, 2017. 


\section{Results and discussions}

\subsection{Results}

Field measurements and calculations are used to derive results from the impact of the conservation of infiltration wells and SDP on surface water in the Pakepon micro watershed and to compare water levels, flow rates and runoff coefficients prior to conservation and after conservation.

\subsubsection{Discharge rating curve}

A discharge rating curve gives the relationship curve between the water flow and the water level. From the calculation with a water level value of $7 \mathrm{~cm}$, a discharge value of $50 \mathrm{~L} / \mathrm{s}$ was obtained, with a water level value of $20 \mathrm{~cm}$, a discharge value of $220 \mathrm{~L} / \mathrm{s}$ was obtained, with a water level value of $44 \mathrm{~cm}$, a discharge rate of $300 \mathrm{~L} / \mathrm{s}$ was obtained, with a water level value of $8 \mathrm{~cm}$, a discharge value of $60 \mathrm{~L} / \mathrm{s}$ was obtained, with a water level value of 39 $\mathrm{cm}$, a discharge value of $250 \mathrm{~L} / \mathrm{s}$ was obtained, with a water level value of $10 \mathrm{~cm}$, a discharge value of $80 \mathrm{~L} / \mathrm{s}$ was obtained. A squared radiant $\left(\mathrm{R}^{2}\right)$ of $0.9437 \mathrm{~cm}$ was found, so it can be concluded there is a good relationship between the discharge and the water level because the squared radiant $\left(\mathrm{R}^{2}\right)$ is close to 1 . The comparison between the calculated discharge flow and the measured water surface level can be seen in the Table 1 and Figure 1 :

Table 1. Measured water level and flow.

Location I

\begin{tabular}{lcccccc}
$\mathrm{H}(\mathrm{cm})$ & 7 & 20 & 44 & 8 & 39 & 10 \\
$\mathrm{Q}(\mathrm{L} / \mathrm{s})$ & 50 & 220 & 300 & 60 & 250 & 80 \\
\hline
\end{tabular}

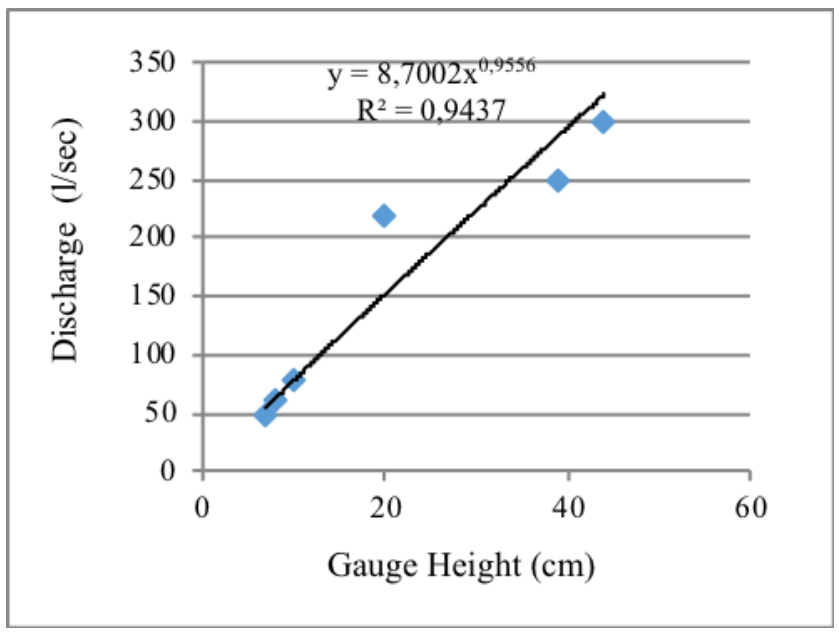

Fig.7. Discharge rating curve of the Pakepon micro-watershed. 
From the calculation result, we obtain the equation of a curve, as shown below:

$$
\mathrm{Q}=8.7 \mathrm{H}^{0.9556}
$$

where

$\mathrm{Q}=$ Discharge flow $\left(\mathrm{m}^{3} / \mathrm{s}\right)$

$\mathrm{H} \quad=$ Water surface level $(\mathrm{m})$

\subsubsection{Discharge hydrograph}

A discharge hydrograph, also known simply as a hydrograph, is a graph of the relationship between the discharge and the time that is converted using a rating curve. Observations were made on April 17, April 20, April 21, April 23 and April 26. The peak of the discharge that occurred on April 17, 2017 was 1302.9 L/s at 15:40, on 20 April 2017 was 1111.2 L/s at 15:00, on 21 April 2017 was 573.0 L/s at 15:00, on 23 April 2017 was 837.4 $\mathrm{L} / \mathrm{s}$ at 17:40 and on 26 April 2017 was $1283.1 \mathrm{~L} / \mathrm{s}$ at 14:40. The results can be seen in Figures 8 to 12 .

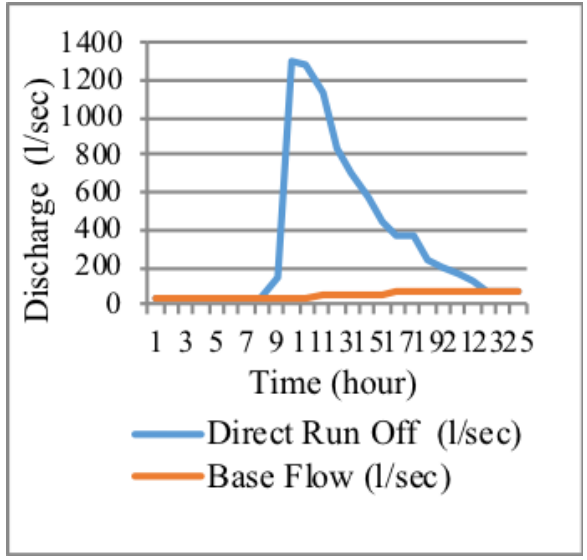

Fig. 8. Discharge hydrograph for April $17^{\text {th }}$.

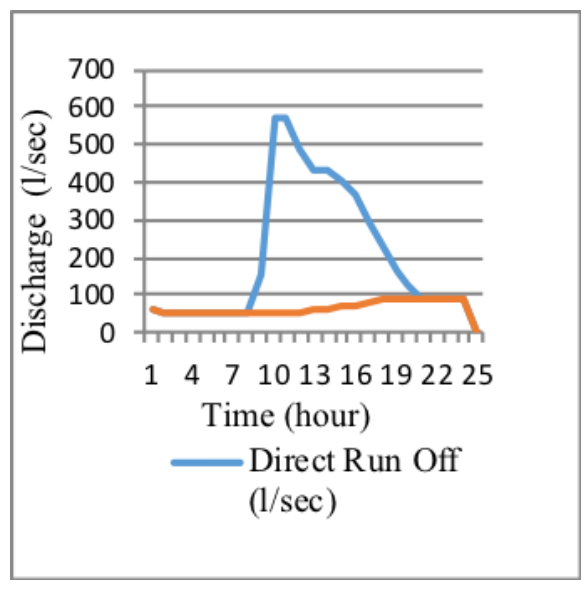

Fig. 10. Discharge hydrograph for April $21^{\text {st }}$.

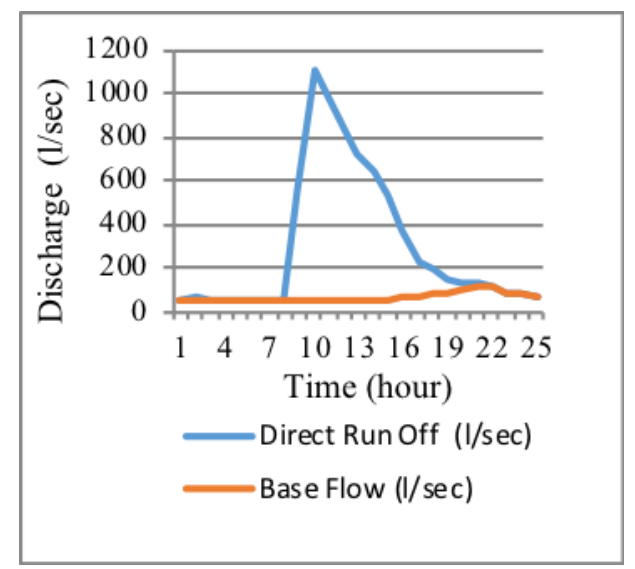

Fig. 9. Discharge hydrograph for April $20^{\text {th }}$.

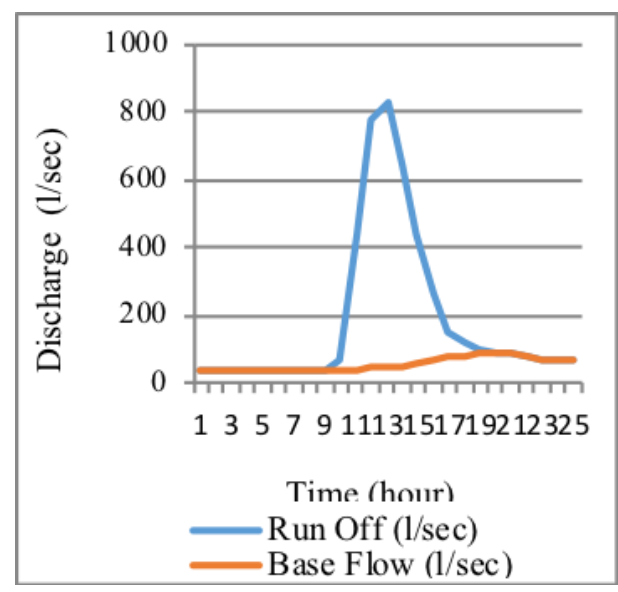

Fig. 11. Discharge hydrograph for April $23^{\text {rd }}$. 


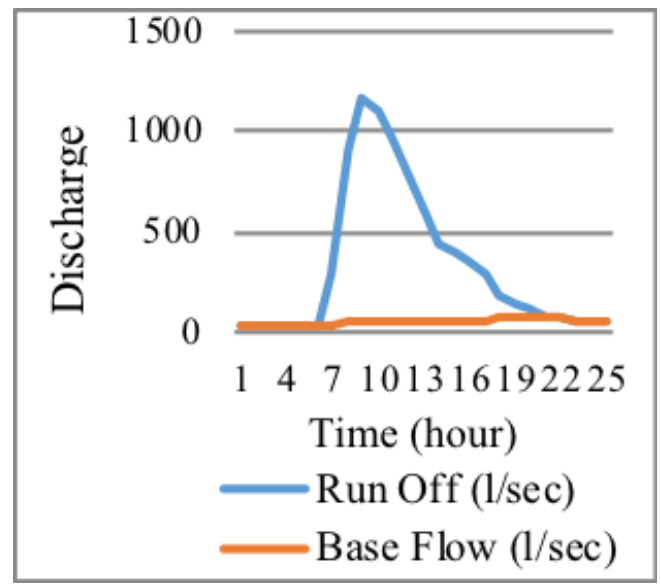

Fig.12. Discharge hydrograph for April $26^{\text {th }}$.

\subsubsection{Conservation technology performance (SDP and infiltration wells)}

Within one year, the volume of rain in the Pakepon micro watershed, with an area of 260.85 hectares, is $6476887 \mathrm{~m}^{3}$. The Pakepon micro watershed area applies 1189 SDP technologies with a $1 \mathrm{~m}$ diameter and a $2.5 \mathrm{~m}$ depth, and an absorption well of 340 pieces with a diameter of $1 \mathrm{~m}$ and a depth of $2 \mathrm{~m}$. The total SDP deposit volume is $3573.11 \mathrm{~m}^{3}$, while the volume of the absorption well is $533657 \mathrm{~m}^{3}$.

In the rainy season (November-April), the total volume of runoff prior to conservation is $2720184 \mathrm{~m}^{3}$, which can broken down into November with $314722 \mathrm{~m}^{3}$, December with $562797 \mathrm{~m}^{3}$, January with $483808 \mathrm{~m}^{3}$, February with $360387 \mathrm{~m}^{3}$, March with $398648 \mathrm{~m}^{3}$ and April with $599823 \mathrm{~m}^{3}$. In the dry season (May-October), the total volume of runoff prior to conservation was $344342 \mathrm{~m}^{3}$, which can be broken down to May with $234499 \mathrm{~m}^{3}$, June with $62944 \mathrm{~m}^{3}$, July with $12342 \mathrm{~m}^{3}$, August with $6171 \mathrm{~m}^{3}$, September with $9874 \mathrm{~m}^{3}$ and October with $18513 \mathrm{~m}^{3}$.

The calculation of runoff volume after conservation uses two scenarios. Scenario 1 is a condition when the water that is accommodated by the SDP and infiltration wells runs out in one day. Scenario 2 is a condition when the water that is accommodated by the SDP and infiltration wells runs out in two days.

From the calculation results for scenario 1, the total volume of runoff after conservation is $2579929 \mathrm{~m}^{3}$. In the rainy season (November-April), the total volume of runoff after conservation is $2309507 \mathrm{~m}^{3}$, with details: in November of $273,654 \mathrm{~m}^{3}$, December at $468,341 \mathrm{~m}^{3}$, January of $397,566 \mathrm{~m}^{3}$, February at $294,679 \mathrm{~m}^{3}$, March at $337,046 \mathrm{~m}^{3}$, and April amounted to $538,221 \mathrm{~m}^{3}$. In the dry season (May-October), the total volume of runoff after conservation was $270,420 \mathrm{~m}^{3}$, with details: in May of $197,538 \mathrm{~m}^{3}$, June of $54,731 \mathrm{~m}^{3}$, July 4,128 $\mathrm{m}^{3}, 2,064 \mathrm{~m}^{3}$ in August, 5,767 $\mathrm{m}^{3}$ in September, October of 6,193 $\mathrm{m}^{3}$. Within one year, the decrease in runoff volume was $484,599 \mathrm{~m}^{3}(15.81 \%)$. 
Table 2. Comparison of rainfall volume, runoff volume before conservation and runoff volume after conservation for scenario 1 .

\begin{tabular}{cccc}
\hline Month & $\begin{array}{c}\text { Rain Fall Volume } \\
\left(\mathrm{m}^{3}\right)\end{array}$ & $\begin{array}{c}\text { Run Off Volume } \\
\text { Before }\left(\mathrm{m}^{3}\right)\end{array}$ & $\begin{array}{c}\text { Run Off Volume } \\
\text { After }\left(\mathrm{m}^{3}\right)\end{array}$ \\
\hline January & 1.022 .529 & 483.808 & 397.566 \\
February & 761.680 & 360.387 & 294.679 \\
March & 842.543 & 398.648 & 337.046 \\
April & 1.267 .727 & 599.823 & 538.221 \\
May & 495.614 & 234.499 & 197.538 \\
June & 133.033 & 62.944 & 54.731 \\
July & 26.085 & 12.342 & 4.128 \\
August & 13.042 & 6.171 & 2.064 \\
September & 20.868 & 9.874 & 5.767 \\
October & 39.127 & 18.513 & 6.193 \\
November & 665.166 & 314.722 & 273.654 \\
December & 1.189 .473 & 562.797 & 468.341 \\
\hline Total & 6.476 .887 & 3.064 .528 & 2.579 .929 \\
\hline Average & $539.740,58$ & $255.377,33$ & $214.994,08$ \\
\hline
\end{tabular}

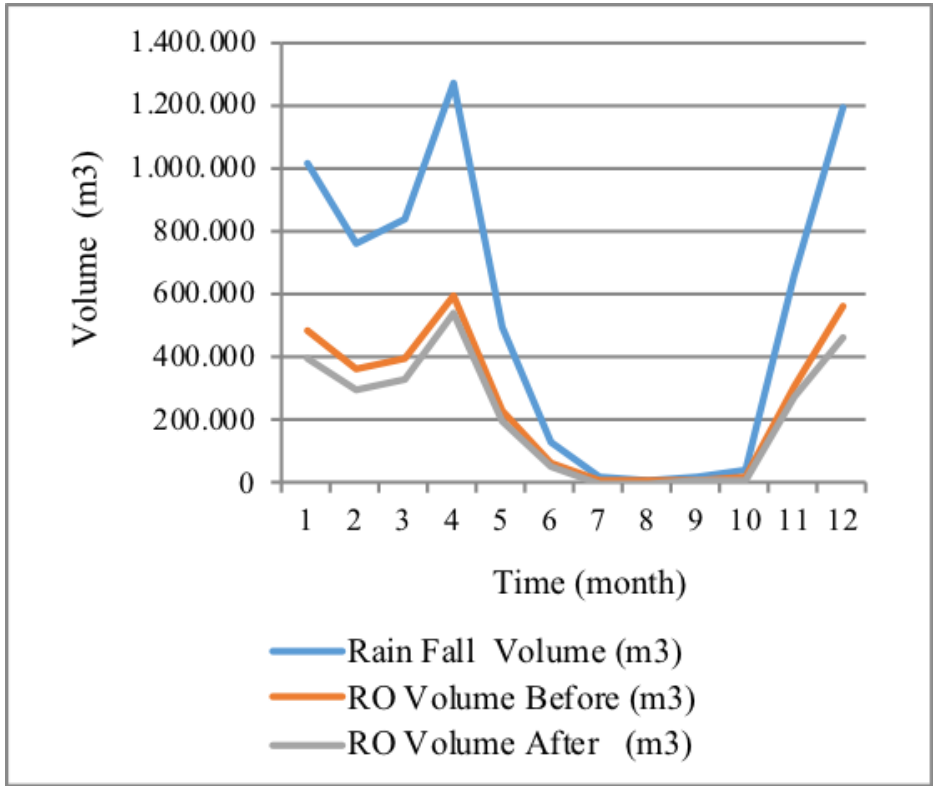

Fig.13. Plot of the comparison of rainfall volume, runoff volume before conservation and runoff volume after conservation scenario 1 .

From the calculation results with scenario 2, the total volume of run off after conservation was $2682598 \mathrm{~m}^{3}$. In the rainy season (November-April), the total volume of runoff after conservation was $2412177 \mathrm{~m}^{3}$, which can be broken down monthly for November at $273654 \mathrm{~m}^{3}$, December at $501195 \mathrm{~m}^{3}$, January at $430420 \mathrm{~m}^{3}$, February at 
$319320 \mathrm{~m}^{3}$, March at $349367 \mathrm{~m}^{3}$ and April amounted to $538,221 \mathrm{~m}^{3}$. In the dry season (May-October), the total volume of runoff after conservation was $270421 \mathrm{~m}^{3}$, with details:

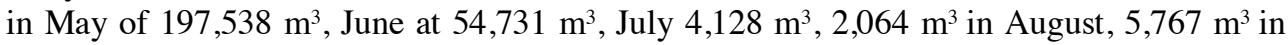
September, October of $6,193 \mathrm{~m}^{3}$. Within one year, the decrease in runoff volume was $381390 \mathrm{~m}^{3}(12.46 \%)$.

Table 3. Comparison of rainfall volume, run off volume before conservation and run off volume after conservation for scenario 2 .

\begin{tabular}{cccc}
\hline Month & $\begin{array}{c}\text { Rain Fall Volume } \\
\left(\mathrm{m}^{3}\right)\end{array}$ & $\begin{array}{c}\text { RO Volume Before } \\
\left(\mathrm{m}^{3}\right)\end{array}$ & $\begin{array}{c}\text { RO Volume After } \\
\left(\mathrm{m}^{3}\right)\end{array}$ \\
\hline January & 1.022 .529 & 483.808 & 430.420 \\
February & 761.680 & 360.387 & 319.320 \\
March & 842.543 & 398.648 & 349.367 \\
April & 1.267 .727 & 599.823 & 538.221 \\
May & 495.614 & 234.499 & 197.538 \\
June & 133.033 & 62.944 & 54.731 \\
July & 26.085 & 12.342 & 4.128 \\
August & 13.042 & 6.171 & 2.064 \\
September & 20.868 & 9.874 & 5.767 \\
October & 39.127 & 18.513 & 6.193 \\
November & 665.166 & 314.722 & 273.654 \\
December & 1.189 .473 & 562.797 & 501.195 \\
\hline Total & 6.476 .887 & 3.064 .528 & 2.682 .598 \\
\hline Average & $539.740,58$ & $255.377,33$ & $223.549,83$ \\
\hline
\end{tabular}

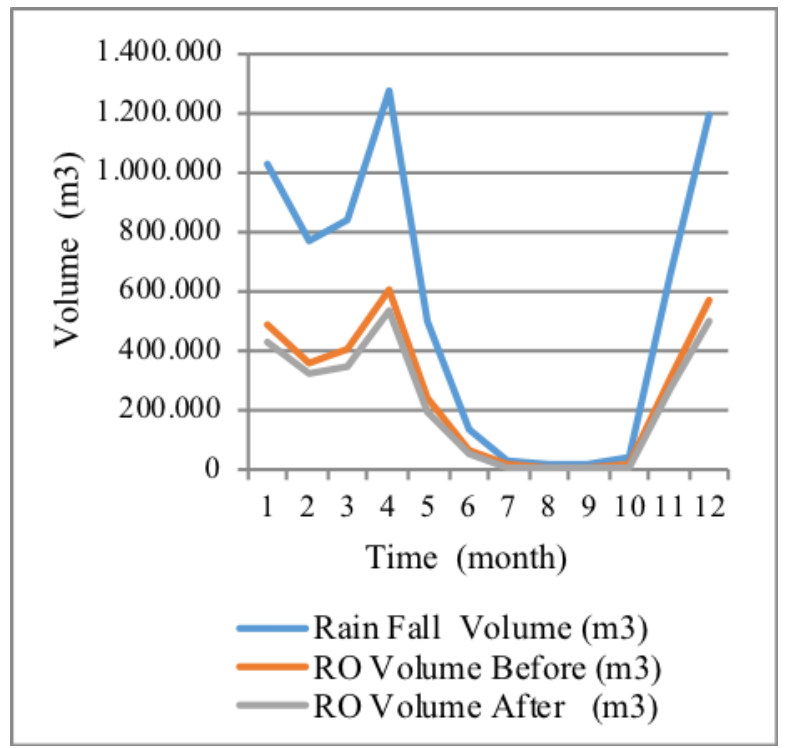

Fig. 14. Plot of the comparison of rainfall volume, runoff volume before conservation and runoff volume after conservation scenario 2 . 
The runoff coefficient is calculated based on the comparison between volume runoff and the amount of rainfall at that time. The result of the coefficient of runoff before conservation is presented in Table 4.

Table 4. Runoff coefficient calculation results .

\begin{tabular}{|c|c|c|c|c|c|c|}
\hline & \multicolumn{5}{|c|}{ Date of Rain } & \multirow[t]{2}{*}{ Average } \\
\hline & April 17th & April 20th & April 21st & April 23rd & April 26th & \\
\hline Rainfall (mm) & 29 & 19 & 10 & 10 & 25 & 18,6 \\
\hline $\begin{array}{l}\text { Watershed } \\
\text { rain volume } \\
\quad\left(\mathrm{m}^{3}\right)\end{array}$ & 75.646 & 49.561 & 26.085 & 26.085 & 65.212 & 48517,96 \\
\hline $\begin{array}{l}\text { Measurement } \\
\text { volume } \\
\left(\mathrm{m}^{3}\right)\end{array}$ & 27.417 & 26.048 & 12.328 & 13.171 & 32.618 & 22316,54 \\
\hline $\begin{array}{c}\text { Runoff } \\
\text { coefficient }\end{array}$ & 0,36 & 0,53 & 0,47 & 0,50 & 0,50 & 0,47 \\
\hline
\end{tabular}

In the rainy season (November-April), the total flow before conservation is $1041.4 \mathrm{~L} / \mathrm{s}$, with a break down in November of $121.4 \mathrm{~L} / \mathrm{s}$, December at $210.1 \mathrm{~L} / \mathrm{s}$, January at $180,6 \mathrm{~L} / \mathrm{s}$, February at $149.0 \mathrm{~L} / \mathrm{s}$, March at $148.8 \mathrm{~L} / \mathrm{s}$, and April at $231.4 \mathrm{~L} / \mathrm{s}$. In the dry season (MayOctober), the total flow rate before conservation is $129.5 \mathrm{~L} / \mathrm{s}$ with details: in May of 87.6 $\mathrm{L} / \mathrm{s}$, June at $24.3 \mathrm{~L} / \mathrm{s}$, July 4, $6 \mathrm{~L} / \mathrm{s}$, August $2.3 \mathrm{~L} / \mathrm{s}$, September at $3.8 \mathrm{~L} / \mathrm{s}$ and October at 6.9 $\mathrm{L} / \mathrm{s}$.

The calculation of discharge after conservation uses two scenarios. Scenario 1 is a condition when the water that is accommodated by the SDP and absorber wells runs out in one day. Scenario 2 is a condition when the water that is accommodated by the SDP and absorption wells runs out in two days.

\subsection{Discussion}

From the calculation of scenario 1, the total flow rate is $986 \mathrm{~L} / \mathrm{s}$. In the rainy season (November-April), the total discharge flow after conservation is $884.16 \mathrm{~L} / \mathrm{s}$, with details: in November of $105.58 \mathrm{~L} / \mathrm{s}$, December at 174.86 liters/sec, January at 148.43 liter/second, February at 121.81 liter/second, March at 125.84 liter/second, and April at 207.65 liter/second. In the dry season (May-October), the total discharge flow after conservation is 101.72 liters/sec, with details: in May of 73.75 liters/sec, June of 21.12 liters/sec, July 1, 54 liters/second, August 0.77 liter/second, September at 2.22 liters/sec, and October at 2.31 liters/sec. Within one year, a decrease of the flow rate of 184.9 liters/second or $15.79 \%$ was obtained. 
Table 5. Comparison of discharge value of rainfall, before conservation and after conservation scenario 1

\begin{tabular}{cccc}
\hline Month & $\begin{array}{c}\text { Discharge Rain Fall } \\
(1 / \mathrm{s})\end{array}$ & $\begin{array}{c}\text { Discharge Before } \\
(1 / \mathrm{s})\end{array}$ & $\begin{array}{c}\text { Discharge After } \\
(1 / \mathrm{s})\end{array}$ \\
\hline January & 381,77 & 180,6 & 148,43 \\
February & 284,38 & 149,0 & 121,81 \\
March & 314,57 & 148,8 & 125,84 \\
April & 473,32 & 231,4 & 207,65 \\
May & 185,04 & 87,6 & 73,75 \\
June & 49,67 & 24,3 & 21,12 \\
July & 9,74 & 4,6 & 1,54 \\
August & 4,87 & 2,3 & 0,77 \\
September & 7,79 & 3,8 & 2,22 \\
October & 14,61 & 6,9 & 2,31 \\
November & 248,34 & 121,4 & 105,58 \\
December & 444,10 & 210,1 & 174,86 \\
\hline Total & $2.418,19$ & $1.170,9$ & 986 \\
\hline
\end{tabular}

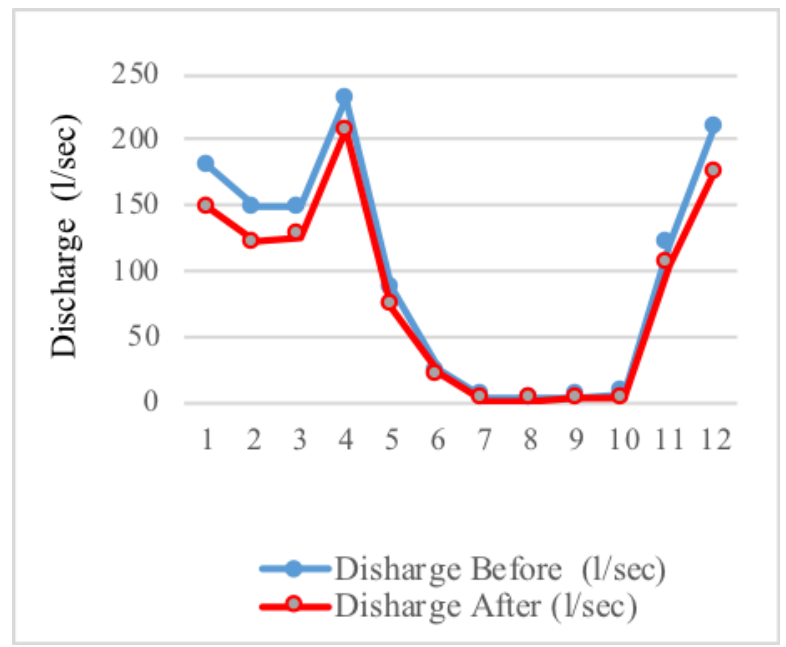

Fig. 15. Comparison of discharge value before conservation and after conservation for scenario 1 .

In the calculation of scenario 2, the total flow rate is $1001.6 \mathrm{~L} / \mathrm{s}$. In the rainy season (November-April), total discharge flow after conservation is 828.4 liters/sec, with details: in November of 10.5 liters/sec, December at 187.1 liters/sec, January at 160.7 liters/second, February amounted to 132 liters/sec, March at 130.4 liters/sec, and April amounted to 207.6 liters/sec. In the dry season (May-October), the total discharge flow after conservation is 101.7 1/sec, with details: in May of 73.8 liters/sec, June at 21.1 liters/sec, July 1, 5 liters/second, August 0.8 liter/second, September at 2.2 liter/second, and October at 2.3 liter/second. Within one year, the flow rate decreased by 184.9 liters/second or $14.46 \%$. 
Table 6. Comparison of discharge value of rainfall, before conservation and after conservation for scenario 2 .

\begin{tabular}{|c|c|c|c|}
\hline Month & $\begin{array}{l}\text { Discharge Rain Fall } \\
(1 / \mathrm{s})\end{array}$ & $\begin{array}{c}\text { Discharge Before } \\
(1 / \mathrm{s})\end{array}$ & Discharge After (l/s) \\
\hline January & 381,77 & 180,6 & 160,7 \\
\hline February & 284,38 & 149,0 & 132,0 \\
\hline March & 314,57 & 148,8 & 130,4 \\
\hline April & 473,32 & 231,4 & 207,6 \\
\hline May & 185,04 & 87,6 & 73,8 \\
\hline June & 49,67 & 24,3 & 21,1 \\
\hline July & 9,74 & 4,6 & 1,5 \\
\hline August & 4,87 & 2,3 & 0,8 \\
\hline September & 7,79 & 3,8 & 2,2 \\
\hline October & 14,61 & 6,9 & 2,3 \\
\hline November & 248,34 & 121,4 & 10,5 \\
\hline December & 444,10 & 210,1 & 187,1 \\
\hline Total & $2.418,19$ & $1.170,9$ & $1.001,6$ \\
\hline
\end{tabular}

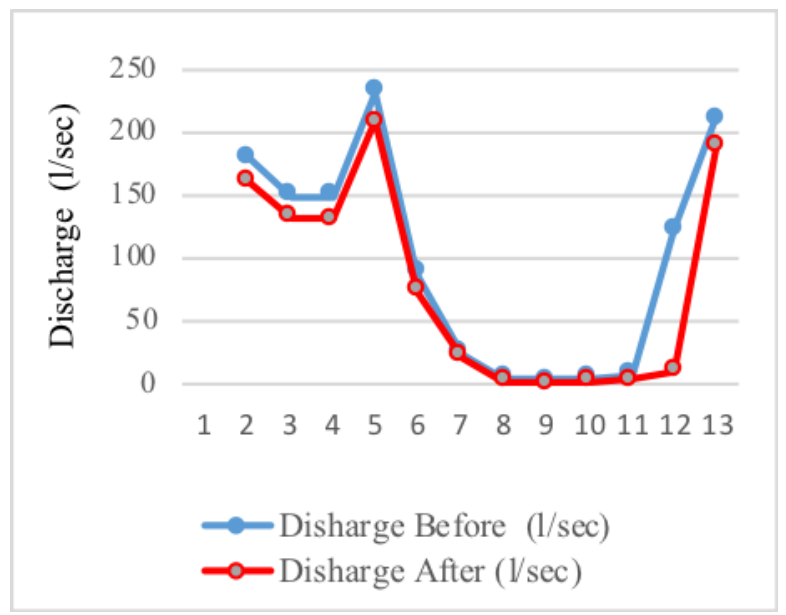

Fig. 16. Comparison of discharge value before conservation and after conservation for scenario 2 .

\section{Conclusions}

Based on the analysis of the micro sub-watershed of Pakepon, the conclusions are:

1. The measured (prior to conservation) flow rate on the Pakepon micro watershed of 260.85 hectares in total for one year is $1,170.9 \mathrm{~L} / \mathrm{s}$ with an average of $97.6 \mathrm{~L} / \mathrm{s}$.

2. Conservation is achieved with the development of SDP technology (Sedrainpond) and infiltration wells. SDP installed a number of 1819 units, with the average diameter of $1 \mathrm{~m}, 2.5 \mathrm{~m}$ deep and a total storage volume of $3573.11 \mathrm{~m}^{3}$. While the infiltration wells 
installed a number of 340 units with an average diameter of $1 \mathrm{~m}, 2 \mathrm{~m}$ deep and a total storage volume of $533.65 \mathrm{~m}^{3}$.

3. Total flow rate after conservation with scenario 1 calculation is 986 liters/sec with an average of 82.2 liters/sec. In the rainy season (November-April), total flow discharge after conservation is 884.16 liter/sec. In the dry season (May-October), the total flow rate after conservation is 101.72 liters/sec. Within one year, a decrease of the flow rate of 184.9 liters/second or $15.79 \%$ was obtained.

4. Total flow discharge after conservation with scenario 2 calculation is 1001,6 liter/second. In the rainy season (November-April), total discharge flow after conservation is 828.4 liters/sec. In the dry season (May-October), the total discharge flow after conservation is 101.7 liters/sec. Within one year, the flow rate decreased by 184.9 liters/second or $14.46 \%$.

5. So based on the calculation result with scenarios 1 and 2, it is better to calculate with scenario 1 because it got the discharge flow value after the conservation is smaller, with the ratio of $1.33 \%$.

\section{Acknowledgments}

The author wishes to express sincere thanks to Semarang District, Central Java Government and Water Resources Laboratory, Civil Engineering Department, Faculty of Engineering, Diponegoro University, Prof. H. Soedarto, SH Street, Tembalang Campus, Semarang for allowing the author to use the facilities of the laboratory.

\section{References}

1. Kumar Kurunthachalam, Senthil, Water Conservation and Sustainability: An Utmost Importance, Hydrol Current Res., (2014)

2. Owombo, P. T., \& Idumah, F. O., Determinants of land conservation technologies adoption among arable crop farmers in Nigeria: A multinomial logit approach, Journal of Sustainable Development, 8(2), 220 (2015)

3. Jorge A. Delgado, Peter M. Groffman, Mark A. Nearing, Tom Goddard, Don Reicosky, Rattan Lal, Newell R. Kitchen, Charles W. Rice, Dan Towery, and Paul Salon, Conservation Practices to Mitigate and Adapt to Climate Change, Journal of Soil and Water Conservation (2011)

4. Sriyana. Penanggulangan Kelangkaan dan Pelimpahan Air MelaluiTeknologi SDP (SeDrainPond) untuk Mendukung Ketahanan Pangan Berbasis Pemberdayan Petani (StudiKasus di Provinsi Jawa Tengah, Prosiding Seminar Nasional INACID "Tema: Strategi Pengelolaan Irigasi dan Rawa Berkelanjutan Mendukung Ketahanan Pangan Nasional dalam Perspektif Perubahan Iklim Global"978-602-70580-0-2 (ISBN), 16-17 Mei 2014 (2014)

5. Balitbang Kimpraswil, Ringkasan Tata Cara Perencanaan Teknik Sumur Resapan Air Hujan Untuk Lahan Pekarangan SNI No.02-2 453-1991 (2001) 